\title{
Viral and bacterial upper respiratory tract infection in hospital health care workers over time and association with symptoms
}

\author{
C. Raina Maclntyre ${ }^{1,2}$, Abrar Ahmad Chughtai ${ }^{1 *}$, Yi Zhang ${ }^{3}$, Holly Seale ${ }^{1}$, Peng Yang ${ }^{3}$, Joshua Chen ${ }^{1}$, Yang Pan ${ }^{3}$, \\ Daitao Zhang ${ }^{3}$ and Quanyi Wang ${ }^{3}$
}

\begin{abstract}
Background: Bacterial colonisation of the respiratory tract is commonly described and usually thought to be of no clinical significance. The aim of this study was to examine the presence and significance of bacteria and viruses in the upper respiratory tract of healthcare workers ( $\mathrm{HCWs}$ ), and association with respiratory symptoms.
\end{abstract}

Methods: A prospective cohort study was conducted in China and 223 HCWs were recruited from fever clinics and respiratory, paediatric, emergency/Intensive medication wards. Participants were followed over 4 weeks (7th May 2015 to 4th June 2015) for development of clinical respiratory illness (CRI). Nasopharyngeal swabs were obtained at baseline and at the end of the study. The primary endpoints were laboratory-confirmed bacterial colonisation and viral respiratory infection. Rates of the following infections in symptomatic and asymptomatic participants were compared at the start or end of the study; 1) all bacterial/viral infections, 2) bacterial infection and bacterial-viral co-infections, excluding virus only infections, and 3) only bacterial infections.

Results: Bacterial colonisation was identified in 88\% (196/223) of participants at the start or end of the study. Among these participants, 66\% (148/223) had only bacterial colonisation while 22\% (48/223) had co-infection with a virus. Bacteria were isolated from 170 (76.2\%) participants at baseline and 127 (57\%) participants at the end of the study. Laboratory confirmed viral infections were identified in 53 (23.8\%) participants - 35 (15.7\%) at the baseline and 20 (9.0\%) at the end of the study.

CRI symptoms were recorded in 12 participants (4.5\%) and all had a positive bacterium isolation at baseline $(n=11)$ or end of the study $(n=1)$. Among asymptomatic participants, $187(87 \%)$ had bacterial colonisation or bacterial/viral co-infection at baseline or end of the study. Viruses were also isolated from 5 (2.4\%) asymptomatic cases. Rates of all infection outcomes were higher in symptomatic participants, however differences were not statistically significant.

Conclusion: We isolated high rates of bacteria and viruses in the upper respiratory tract of hospital HCWs, which may reflect greater exposure to respiratory infections in the hospital. Although respiratory infections are mostly symptomatic, the association between bacterial colonization and symptomatic illness is not clear. In the healthcare setting, HCWs may acquire and transmit infection to patients and other HCWs around them. Larger studies are required to explore ongoing occupational risk of respiratory infection in hospitals HCWs.

Keywords: Bacterial colonisation, Masks, Respiratory infections, Infection control

\footnotetext{
* Correspondence: abrar.chughtai@unsw.edu.au

${ }^{1}$ School of Public Health and Community Medicine, UNSW Medicine,

University of New South Wales, Level 2, Samuels Building, Sydney 2052,

Australia

Full list of author information is available at the end of the article
} International License (http://creativecommons.org/licenses/by/4.0/), which permits unrestricted use, distribution, and reproduction in any medium, provided you give appropriate credit to the original author(s) and the source, provide a link to the Creative Commons license, and indicate if changes were made. The Creative Commons Public Domain Dedication waiver (http://creativecommons.org/publicdomain/zero/1.0/) applies to the data made available in this article, unless otherwise stated. 


\section{Background}

The significance of finding pathogenic bacteria in the upper respiratory tract is unknown, as it is generally thought that many people are asymptomatic carriers of colonising bacteria [1-3]. To date, there has been very little research looking at the role of upper respiratory tract bacteria as a cause of mild respiratory illness. Healthcare workers (HCWs) are at high risk of nosocomial infection with respiratory, blood borne and other infections [4-6]. Respiratory infections are the leading cause of acute infections in humans. Whilst the burden of disease is well recognised in the elderly and immunocompromised, limited information exists on the impact of respiratory infections on HCWs [6-8]. Nosocomial infections among HCWs result in increased rates of illness, absenteeism and even death amongst HCWs [5, 9] and also comes at a large financial cost to the health care system [10]. HCWs may also be a source of infection in nosocomial outbreaks [11]. Transmission of influenza from patient-to-HCW and HCW-to-patient have been identified in many cases highlighting the importance HCWs play in hospital transmission [12].

Varying degrees of nasopharyngeal (NP) bacterial colonisation are reported in healthy individuals, depending on the age of participants, site of specimen collection and vaccination status $[13,14]$. Certain factors increase the risk of nasopharyngeal carriage such as age, geographical area, vaccination status, immunity and socio-economic status [1, 13-15]. There are limited data from HCWs, and most studies are conducted in children, who generally have higher rates of NP colonisation compared to adults $[3,16]$. Commonly isolated organisms are Streptococcus pneumoniae (pneumococcus), Haemophilus influenzae, Moraxella catarrhalis and Staphylococcus aureus [17]. Testing of healthy children showed 50\% NP carriage rate for S. aureus [13], 55-69\% for Streptococcus pneumoniae [13, 14, 18], 67-74\%for Moraxella. catarrhalis [13, 14] and 57-83\% for Haemophilus influenzae [13, 14, 18].

In a study of both inpatients and outpatient children the overall swab positivity rates were 31.5\% (63/200), with Streptococcus pneumoniae, Haemophilus influenzae and Group A Streptococcus accounting for 22\%, 5\% and $4.5 \%$ respectively [19]. In a study in Italy, the rate of Streptococcus pneumoniae, Haemophilus influenzae, and Moraxella catarrhalis found 3.5\%, $11.9 \%$ and $4.1 \%$ carriage respectively (overall 17.9\%) [20]. In Australian Aboriginal adults, rates of bacterial colonisation were $26 \%, 23 \%$ and $17 \%$ for Streptococcus pneumoniae, Haemophilus influenza and Moraxella catarrhalis respectively [14]. Lower carriage rates of Haemophilus influenzae (0\%) and Streptococcus pneumoniae (10.8\%) were observed in a study in China [18]. An Australian study also reported very low rate (1/315) of Streptococcus pneumoniae in hospitalised elderly patients [21].
The finding of a virus in the upper respiratory tract is generally thought to be clinically significant. However the significance of asymptomatic viral infection has not been explored in existing literature, and viruses detected in the upper respiratory tract are generally assumed to be pathogenic. Some studies have found that up to 1 in 3 subjects with influenza infection may be asymptomatic [22], whilst asymptomatic infection with parainfluenza virus has also been observed [23]. One study also demonstrated shedding of parainfluenza virus from healthy subjects over an extended period of time [24]. Whilst little research exists on asymptomatic viral infections, these cases suggest that viruses can be transmitted by asymptomatic subjects unknowingly. A better understanding of the role of bacterial and viral infections in HCWs and their association with the respiratory symptoms is warranted. The aim of this study was to examine the presence and significance of bacteria and viruses in the upper respiratory tract of HCWs.

\section{Methods}

A prospective cohort study was conducted in four hospitals in Beijing, China. Participants were hospital HCWs aged between 18 and 65 from respiratory wards, paediatric wards, intensive care unit, outpatient fever clinics (special clinics in Chinese hospitals for management of febrile patients) and emergency units. Participants were followed over a 4 week period and were asked to report any symptoms that developed over the study period. Recruitment formally commenced on the 7th of May 2015 and final follow up was completed on the 4th of June 2015.

\section{Eligibility}

HCWs (doctors and nurses) from the selected wards of four hospitals were invited to participate in the study. Full-time HCWs, aged 18 and over were eligible for participation in the study. Participants were excluded if they: [1] were unable or refused to consent; [2] had a current respiratory illness; rhinitis and/or allergy; [3] work part-time or [4] were not available for the 4 weeks follow-up.

\section{Recruitment}

Information about the study was provided to staff members by district level staff members from the Beijing Centre for Disease Prevention and Control (CDPC). Hospital staffs were invited to attend information sessions, which were held at different times of the day. Information sheets and consent forms were given out during these sessions and interested staff members asked to return the completed forms if they had agreed to give consent and participate in the study. Additional copies of the participant information sheet were also left with designated staff members from 
each ward to pass onto staff members who were unable to attend the information sessions.

\section{Data collection and follow up}

At time of recruitment, baseline nasopharyngeal swabs were collected by trained staff and tested in the Beijing CDPC laboratory. Detailed demographic and clinical details for all participants were also collected. This included age, sex, smoking history, comorbidities, vaccination status, medications, use of personal protective equipment, performing high risk procedures, antivirals and results of laboratory tests.

At the end of the 4 weeks, another set of nasopharyngeal swabs was collected from all participants. A second (exit) survey was administered at the same time to participants to collect information about the development of any respiratory symptoms in the previous 4 weeks. Clinical respiratory illness (CRI) was defined as two or more respiratory symptoms (cough, nasal congestion, runny nose, sore throat or sneezes) or one respiratory symptom and a systemic symptom (chill, lethargy, loss of appetite, abdominal pain, muscle or joint aches).

The primary endpoints were:

(1) Laboratory-confirmed bacterial colonisation in symptomatic/non-symptomatic subjects. Multiplex PCR was used to test for Streptococcus pneumoniae, Legionella, Bordetella pertussis, chlamydia pneumoniae, Mycoplasma pneumoniae or Haemophilus influenzae type B (Seegen, Inc., Seoul, Korea).

(2) Laboratory-confirmed viral respiratory infection in symptomatic/non-symptomatic subjects, defined as detection of Adenoviruses, Human metapneumovirus, Coronaviruses 229E/NL63 and OC43/HKU1, Parainfluenzaviruses 1, 2 and 3, Influenza viruses $A$ and $B$, Respiratory syncytial viruses $A$ and $B$, or Rhinoviruses $A / B$ by nucleic acid testing (NAT) using a commercial multiplex polymerase chain reaction (PCR) (Seegen, Inc., Seoul, Korea) [25].

\section{Specimen collection and testing}

Double rayon-tipped, plastic-shafted swabs were used to scratch both tonsilar areas and the posterior pharyngeal wall of participants. These samples were then transported immediately after collection to the Beijing CDPC laboratories, or stored at $4{ }^{\circ} \mathrm{C}$ for up to $48 \mathrm{~h}$ if transport is delayed. Viral DNA/RNA was extracted from each respiratory specimen using the Viral Gene-spinTM Kit (iNtRON Biotechnology, Inc., Seoul, Korea) according to the manufacturer's instructions. Reverse transcription was performed using the RevertAidTM First Strand cDNA Synthesis Kit (Fermentas, ON, Canada) to synthesise cDNA. Multiplex PCR was carried out using the Seeplex ${ }^{\circ}$ RV12 Detection Kit (Seegen, Inc., Seoul, Korea). A mixture of clones of the 12 viruses tested was used as a positive control template, and sterile deionised water was used as a negative control. Viral isolation by MDCK cell culture was undertaken for some of the influenza samples that are influenza NAT positive. NAT using a multiplex PCR was also done on the same DNA/RNA extract as used for the viral PCR (Seegen, Inc., Seoul, Korea). Specimen processing, DNA/RNA extraction, PCR amplification, and PCR product analyses were conducted in different rooms to avoid cross-contamination.

\section{Analysis}

Rates of bacterial, viral and co-infections were measured at the start and end of the study period and were also compared in symptomatic and non-symptomatic participants. We performed analysis considering three outcomes. First we compared rates of all bacterial infection at the start or end of the study including bacterial/viral co-infections, in symptomatic and asymptomatic participants. Then we compared rates of bacterial infection and co-infection in symptomatic and asymptomatic participants - five cases with viral only infections were excluded from this analysis. Finally we compared rates of only bacterial infection excluding viral co-infection, in symptomatic and asymptomatic participants.

The primary endpoints of interest were analysed by binary logistic regression models. Univariate analyses were performed for main exposure variable and other variables such as age, sex, occupation, vaccination status, performing high-risk procedures, mask use, smoking status, preexisting illness, respiratory symptoms within the family and ward type. Multivariate analyses were also performed and all variable were included in the model. The data were analysed using SAS v. 9.4 (SAS Institute Inc., USA).

\section{Sample size}

Sample size was based on 95\% confidence and $80 \%$ power to detect difference between rates of bacterial colonisation in symptomatic and asymptomatic individuals, if we assume $20 \%$ of $\mathrm{HCW}$ will have bacterial colonization. These estimates are based on previous studies that describe adult colonisation rates. The sample size was calculated in Epi Info 2000 [26]. In order to allow for loss to follow up, 220 hospital staff members were to be recruited.

\section{Ethics approval}

The study protocol was approved by the Human Research Ethics Committee of the Beijing Ministry for Health and HREC University of New South Wales (HC14325).

\section{Results}

A total of 223 participants were recruited from four hospitals and followed for 4 weeks. Most participants were female $(84.3 \%)$, with a graduate degree $(71.3 \%)$ and 
were not vaccinated for influenza (78.5\%) during the study season (Table 1). The mean age of participants was 36.7 years (SD \pm 9.7 and range $20-65$ years) and around half of them were doctors. Thirteen percent $(29 / 223)$ of participants had at least one pre-existing medical condition and 64\% (143/223) had performed high risk procedures during the study period.

Bacteria were isolated from 170 (76.2\%) participants at baseline and 127 (57\%) participants at the end of the

Table 1 Demographic characteristics of participants $(n=223)$

\begin{tabular}{|c|c|c|}
\hline Variable & Number & Precent/mean SD \\
\hline \multicolumn{3}{|l|}{ Gender } \\
\hline Male & 35 & 15.7 \\
\hline Female & 188 & 84.3 \\
\hline Age & & 36.7 ( \pm 9.7 SD) \\
\hline \multicolumn{3}{|l|}{ Profession } \\
\hline Doctor & 104 & 46.6 \\
\hline Nurses & 119 & 53.4 \\
\hline \multicolumn{3}{|l|}{ Education } \\
\hline Undergraduate & 37 & 16.6 \\
\hline Graduate & 159 & 71.3 \\
\hline Post graduate & 27 & 12.1 \\
\hline \multicolumn{3}{|l|}{ Smoking status } \\
\hline Current/ex-smoker & 11 & 4.9 \\
\hline Never & 212 & 95.1 \\
\hline \multicolumn{3}{|l|}{ Influenza vaccine } \\
\hline Yes & 48 & 21.5 \\
\hline No & 175 & 78.5 \\
\hline \multicolumn{3}{|l|}{ Medical conditions ${ }^{a}$} \\
\hline Yes & 29 & 13.0 \\
\hline No & 194 & 87.0 \\
\hline \multicolumn{3}{|l|}{ High risk procedures ${ }^{\mathrm{b}}$} \\
\hline Yes & 143 & 64.1 \\
\hline No & 80 & 35.9 \\
\hline \multicolumn{3}{|l|}{ Ward } \\
\hline Respiratory & 99 & 44.4 \\
\hline Paediatric & 47 & 21.1 \\
\hline Fever clinics & 31 & 13.9 \\
\hline Emergency/Intensive medication ${ }^{c}$ & 46 & 20.6 \\
\hline \multicolumn{3}{|l|}{ Hospital } \\
\hline A & 50 & 22.4 \\
\hline B & 55 & 24.7 \\
\hline C & 57 & 25.6 \\
\hline$D$ & 61 & 27.4 \\
\hline
\end{tabular}

anclude asthma, diabetes, immunosuppression and other

${ }^{\mathrm{b}}$ Include suctioning of airways, endotracheal intubation, sputum induction, chest, physiotherapy bronchoscopy

${ }^{c} 45$ cases in emergency and 1 in intensive medication unit study (Table 2). If co-infections were excluded, bacteria were isolated from $57 \%$ participants $(128 / 223)$ at baseline and 44\% (98/223) at end of the study. Overall 196 (88\%) participants had bacterial colonisation at start or end of the study - 148 participants (66\%) had only bacterial colonisation while $48(22 \%)$ participants had co-infection with a virus (Fig. 1a). Among the total participants, 101 (45.5\%) were positive for bacteria at both baseline and end of the study, 68 (30.6\%) were positive at baseline and negative at the end, $26(11.7 \%)$ were negative at baseline and positive at the end and $27(12.2 \%)$ were negative at both periods (Fig. 1b). Among all bacterial positive cases, Streptococcus pneumoniae (isolated or co-infected with Haemophilus influenza) was the most commonly isolated organism at baseline $(96 \%, 163 / 170)$ and end of the study (72\%, 91/127). Sixty-seven cases were positive for Streptococcus pneumoniae at both baseline and end of the study 18 from respiratory ward $(18 \%, 18 / 99), 18$ from paediatric ward $(38 \%, 18 / 47), 9$ from fever clinics $(29 \%, 9 / 31)$ and 22 from emergency ward $(48 \%, 22 / 46)$.

There were 35 (15.7\%) laboratory confirmed viral infections found at baseline and $20(9.0 \%)$ found at the end of the study (Table 2). Rhinovirus/enterovirus was the most common viral pathogen accounting for 24 (10.8\%)

Table 2 Laboratory results $(n=223)$

\begin{tabular}{|c|c|c|c|c|}
\hline & $\begin{array}{l}\text { Number } \\
\text { at the } \\
\text { baseline }\end{array}$ & $\%$ & $\begin{array}{l}\text { Number } \\
\text { at the end } \\
\text { of study }\end{array}$ & $\%$ \\
\hline \multicolumn{5}{|l|}{ Bacteria isolated } \\
\hline Streptococcus pneumoniae & 98 & 43.9 & 38 & 17 \\
\hline Haemophilus influenzae & 7 & 3.1 & 36 & 16.1 \\
\hline $\begin{array}{l}\text { Streptococcus pneumoniae and } \\
\text { Haemophilus influenzae }\end{array}$ & 65 & 29.1 & 53 & 23.8 \\
\hline All bacteriac & 170 & 76.2 & $127^{\mathrm{b}}$ & 57 \\
\hline Only bacteria (no co-infection) & 128 & 57.4 & 98 & 43.9 \\
\hline \multicolumn{5}{|l|}{ Virus isolated } \\
\hline Rhinovirus/Enterovirus & 24 & 10.8 & 10 & 4.5 \\
\hline Influenza A (H3N2) & 6 & 2.7 & 5 & 2.2 \\
\hline $\begin{array}{l}\text { Rhinovirus/Enterovirus/Influenza } \\
\text { A (H3N2) }\end{array}$ & 1 & 0.4 & 0 & 0 \\
\hline Other $^{d}$ & 4 & 1.8 & 5 & 2.2 \\
\hline All virus ${ }^{c}$ & 35 & 15.7 & 20 & 9.0 \\
\hline Only virus (no co-infection) & 3 & 1.3 & 2 & 0.9 \\
\hline Co-infection & 29 & 13.0 & 11 & 4.9 \\
\hline
\end{tabular}

${ }^{a} 101$ cases were positive at both baseline and end of the study ${ }^{\mathrm{b}}$ Including 26 new positive samples which were negative at baseline 'One participant was not sampled at end of the study. Among 35 cases at baseline - 14 were from respiratory ward, 6 from paediatric ward, 8 from fever clinics and 7 from emergency ward. Among 20 cases at the end of the study 7 were from respiratory ward, 8 from paediatric ward, 1 from fever clinics and 4 from emergency ward

dAt baseline other includes ADV [1], CoV229E [1], CoVC229E [1], Metapneumovirus [1] and at the end of the study other includes ADV [2], CoV229E [1], CoVC229E [1], Metapneumovirus [1] 


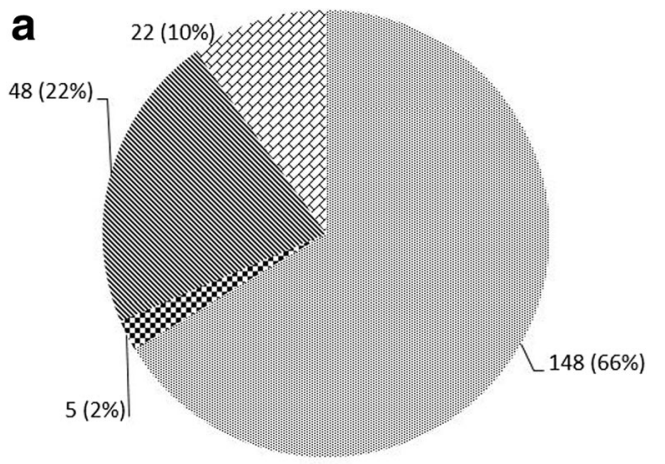

$$
\begin{aligned}
& \text { O. Only bacterial infection } \\
& \$ \text { Only viral infection } \\
& \text { Mixed infection } \\
& \text { No infection }
\end{aligned}
$$

b

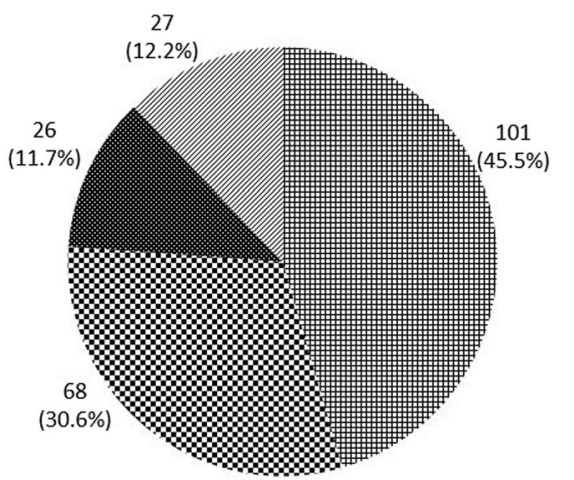

\# Baseline and end of study pos

$\mathbf{x}$ Baseline pos and end of study

neg

Baseline neg and end of study

pos

" Baseline and end of study neg

Fig. 1 a Rates of bacterial, viral and co-infections; b Bacterial colonisation at baseline and at end of the study

and $10(4.5 \%)$ infections at baseline and the end respectively. Other viruses detected included Adenovirus, Coronavirus, H1N1 and H3N2 influenza virus and human metapneumovirus. Rates of bacterial/viral coinfections were $13 \%(29 / 223)$ at baseline and $4.9 \%(11 /$ 223) at the end of the study.

Twelve participants (4.5\%) developed clinical respiratory illness (CRI) during the 4 week study period and all of these $12 \mathrm{HCWs}$ had positive bacteria isolation at baseline ( $n=11$, including 4 co-infection with a virus) or end of the study $(n=1)$. Among asymptomatic participants, 187 (87\%) had bacterial colonisation or co-infection at baseline or end of the study. Viruses were also isolated from 5 (2.4\%) of asymptomatic cases (Table 3 ).

Rates of bacterial colonisation were compared among symptomatic and non-symptomatic participants in the Table 4. In all three outcomes, rates of bacterial colonisation were higher in symptomatic participants, compared to non-symptomatic, although differences were not statistically significant.
In univariate analysis, rates of bacterial colonisation were higher (OR 0.31, 95\% confidence interval 0.12 to 0.75 ) in females $(90.4 \%, 170 / 188)$ compared to males $(74.3 \%, 26 / 35)$ however this was not statistically significant (Table 5 ). No other variable was associated with bacterial colonisation.

\section{Discussion}

We found a very high rate of bacterial colonisation in HCWs, especially Streptococcus pneumonia, with fluctuation in infections over a period of weeks. Almost $88 \%$ of all HCWs had bacteria detected in the nasopharynx at baseline, the end of the study period or both. This is a much higher rate of colonisation compared to other studies of adults. For example, other studies of adults show rates of $5-20 \%[27,28]$. We have previously shown only $0.3 \%$ of elderly subjects carry pneumococcus in the nasopharynx. The finding of such a high rate in this HCW population may reflect greater exposure to respiratory infections in the hospital setting and confirms the continual, ongoing risk to HCWs in the hospital setting.

Table 3 Rates of bacterial, viral and co-infection among symptomatic and asymptomatic participants

\begin{tabular}{llllll}
\hline Symptomatic (CRI) & Bacterial colonisation & Viral infection & Co-infection & Negative swab & Total \\
\hline Yes (12) & $8(66.7 \%)$ & 0 & $4(33.3 \%)$ & 0 & $12(100 \%)$ \\
No (213) & $140(66.4 \%)$ & $5(2.4 \%)$ & $44(20.9 \%)$ & $22(10.4 \%)$ & $211(100 \%)$ \\
\hline
\end{tabular}


Table 4 Comparing rates of bacterial colonisation in symptomatic and non-symptomatic participants

\begin{tabular}{|c|c|c|c|c|}
\hline CRI & Bacterial colonisation & Rate (\%) & OR & $P$ value \\
\hline \multicolumn{5}{|c|}{$\begin{array}{l}\text { All bacteria positive at start or end of the study (including bacteria/viral } \\
\text { co-infections) }(n=223)\end{array}$} \\
\hline Yes & $12 / 12$ & 100 & $3.7(0.19-72.55)$ & 0.385 \\
\hline No & $184 / 211$ & 87.2 & Ref & \\
\hline
\end{tabular}

All bacteria positive at start or end of the study (excluding virus only infection) $(n=218)$

$\begin{array}{lllll}\text { Yes } & 12 / 12 & 100 & 3.1(0.16-59.69) & 0.463 \\ \text { No } & 184 / 206 & 89.3 & \text { Ref } & \end{array}$

Only bacterial infection, excluding viral and co-infection infection cases $(n=170)$

\begin{tabular}{lllll} 
Yes & $8 / 8$ & 100 & $2.72(0.13-57.84)$ & 0.521 \\
No & $140 / 162$ & 86.4 & & \\
\hline
\end{tabular}

Respiratory infections in hospital HCWs are of particular concern due to the risk of transmission to patients who are ill and/or immunocompromised. Respiratory tract infections generally present with symptoms such as fever, tachypnea, shortness of breath and cough. However the relationship of bacterial colonization to symptomatic illness has not been studied extensively. We found a very high and dynamic rate of bacterial colonisation in hospital HCWs, with changes from baseline to the end of the follow up period in the individuals with infection as well as the types of infection.

Colonisation is important as this may progress to invasive disease [1]. Bacterial colonisation may be an important source of horizontal spread of infection within the community [1]. Among $170 \mathrm{HCWs}$ with positive bacterial result at baseline, 68 (40\%) became negative at the end of the study. Natural clearance of bacteria in asymptomatic and symptomatic subjects has not yet been studied. The rates of bacterial colonisation in symptomatic HCWs were higher than in asymptomatic HCWs, but this was not significant. Bacterial colonisation in the majority of the HCWs resolved without any treatment or development of symptoms. We found 12 cases of CRI developed over 4 weeks, 11 of which had bacterial colonisation at baseline. If bacterial shedding occurs asymptomatically, then a large amount of undetected transmission may be occurring in hospitals. This may be important for bacteria such as pneumococcus, where the transition from carriage to invasive disease is thought to occur soon after acquisition of infection.

Of interest, we identified 5 cases of asymptomatic viral infection - four rhinovirus/enterovirus and one influenza A(H3N2). Few studies have been conducted on the incidence of asymptomatic viral infection, and of these, the results are often inconsistent. One study examined the rate of asymptomatic infection resulting from inoculation and found that $1 / 3$ of participants did not develop any symptoms [23] whereas a more recent study found the rate of respiratory illness attributable to influenza infection to be 27 respiratory illnesses per 100 persons [29]. Our findings indicated a high rate of asymptomatic infection at baseline, being cleared without the development of symptoms. The clinical significance of such findings is still unknown with limited information on viral shedding and transmission in asymptomatic subjects. It is well known that influenza virus is shed from the respiratory tract in the incubation period in asymptomatic subjects, and asymptomatic infection has also been observed with parainfluenza virus infection [22]. It has also been found that viral shedding of influenza occurs on average for 5 days after infection, indicating that some positive tests could have been in HCWs recovering from influenza [22]. Asymptomatic viral infections pose a significant risk of nosocomial transmission to both patients and HCWs.

We found many co-infections in this study. Previous studies have demonstrated that a viral infection may facilitate bacterial colonisation or co-infection with $S$. pneumoniae [30]. This may be a significant concern as such co-infection has been associated with significantly higher morbidity and mortality [31]. A growing body of evidence suggests that the risk of bacterial respiratory infections is increased by co-infection with viruses and vice-versa, however bacterial respiratory tract infections are generally not considered a major occupational hazard. Despite documented outbreaks of Bordetella pertussis, Chlamydia pneumoniae and Mycoplasma pneumoniae [32-36], there are few prospective studies of bacterial respiratory infections or colonization, nor consideration of the clinical implications for HCWs. The risk of coinfection has been reported in schools and daycare centres with subsequent community transmission [3], but not in HCWs. It has also been suggested that viral infection may facilitate bacterial colonisation of the respiratory tract particularly with S. pneumoniae. Studies in mice have found that influenza virus infection increases the transmission and burden of pneumococcal disease [30]. Similar findings have been reported in other studies demonstrating significantly higher morbidity and mortality of cases with influenza virus co-infection with S. pneumoniae [37]. This is suggestive that the role and significance of viral infection in the nasopharynx may be complex, highlighting the need for further research into this topic.

Being a healthcare provider has been identified as a major risk factor for respiratory infections [38, 39], however even within HCWs, the risk varies significantly. Hand hygiene, use of personal protective equipment (PPE) and working on intensive care units (ICUs) have been associated with risk of influenza [40]. Interestingly, factors such as vaccination status, performing high-risk procedures, working on respiratory and paediatric wards and smoking were not found to be significant in predicting bacterial colonisation in this study. Smoking, influenza vaccination 
Table 5 Univariate and multivariate analysis $(n=223)$

\begin{tabular}{|c|c|c|c|c|c|}
\hline Variable & Bacterial colonisation & Rate & OR $(95 \% \mathrm{Cl})$ & AOR $(95 \% \mathrm{Cl})$ & $P$ value \\
\hline \multicolumn{6}{|l|}{ CRI } \\
\hline Yes & $12 / 12$ & 100 & 3.72 (0.19 to 72.55$)$ & 3.64 (0.22 to 60.36) & 0.367 \\
\hline No & $184 / 211$ & 87.2 & Ref & Ref & \\
\hline \multicolumn{6}{|l|}{ Gender } \\
\hline Male & $26 / 35$ & 74.3 & 0.31 (0.12 to 0.75$)$ & 0.33 (0.11 to 1.01$)$ & 0.052 \\
\hline Female & $170 / 188$ & 90.4 & Ref & Ref & \\
\hline Age & & & 0.97 (0.93 to 1.02) & 0.98 (0.93 to 1.03$)$ & 0.549 \\
\hline \multicolumn{6}{|l|}{ Profession } \\
\hline Doctor & $89 / 104$ & 85.6 & 0.66 (0.30 to 1.49$)$ & 0.92 (0.32 to 2.59) & 0.869 \\
\hline Nurses & $107 / 119$ & 89.9 & Ref & Ref & \\
\hline \multicolumn{6}{|l|}{ Smoking status } \\
\hline Current/ex-smoker & $8 / 11$ & 72.7 & 0.34 (0.08 to 1.37$)$ & 0.54 (0.12 to 2.42$)$ & 0.418 \\
\hline Never & $188 / 212$ & 88.7 & Ref & Ref & \\
\hline \multicolumn{6}{|l|}{ Influenza vaccine } \\
\hline Yes & $42 / 48$ & 87.5 & 0.95 (0.36 to 2.52) & $0.69(0.26$ to 1.86$)$ & 0.463 \\
\hline No & $154 / 175$ & 88 & & & \\
\hline \multicolumn{6}{|l|}{ Medical conditions $^{a}$} \\
\hline Yes & $25 / 29$ & 86.2 & 0.84 (0.27 to 2.63) & 0.77 (0.24 to 2.46$)$ & 0.664 \\
\hline No & $171 / 194$ & 88.1 & Ref & Ref & \\
\hline \multicolumn{6}{|l|}{ High risk procedures ${ }^{\mathrm{b}}$} \\
\hline Yes & $124 / 143$ & 86.7 & 0.72 (0.30 to 1.74$)$ & 0.72 (0.26 to 2.01$)$ & 0.528 \\
\hline No & $72 / 80$ & 88.9 & Ref & Ref & \\
\hline \multicolumn{6}{|l|}{ Mask use } \\
\hline Yes & $172 / 196$ & 87.8 & 0.90 (0.25 to 3.20$)$ & 0.83 (0.24 to 2.82 ) & 0.765 \\
\hline No & $24 / 27$ & 88.9 & Ref & Ref & \\
\hline \multicolumn{6}{|l|}{ Ward } \\
\hline Respiratory & $81 / 99$ & 81.8 & Ref & Ref & \\
\hline Paediatric & $44 / 47$ & 93.6 & 3.26 (0.91 to 11.68$)$ & 2.72 (0.78 to 9.47$)$ & 0.117 \\
\hline Fever clinics & $29 / 31$ & 93.5 & 3.22 (0.70 to 14.75$)$ & 2.62 (0.56 to 12.24$)$ & 0.221 \\
\hline Emerg/ICU & $42 / 46$ & 91.3 & 2.33 (0.74 to 7.38$)$ & $2.52(0.77$ to 8.24$)$ & 0.126 \\
\hline
\end{tabular}

Bold shows significant result

anclude asthma, diabetes, immunosuppression and other

${ }^{b}$ Include suctioning of airways, endotracheal intubation, sputum induction, chest, physiotherapy bronchoscopy

${ }^{\mathrm{c}} 45$ cases in emergency and 1 in intensive medication unit

status and ward type in hospitals have been previously identified as risk factors for respiratory infection in various groups $[40,41]$ however our findings suggest that such risk factors may not be absolute and may vary in different situations. The effect of vaccination also needs to be studied. Some studies show that pneumococcal vaccination may reduce colonisation with vaccine-serotype pneumococcal infection, though replacement by other strains reduces the overall effect [1]. Previous studies showed that medical masks and respirators reduce the risk of bacterial respiratory infections [42], which further supports the occurrence of nosocomial transmission of bacteria.
The limitations of this study include that we did not test for bacterial or viral infection at the time of reported symptoms. This would confirm that an infection was the cause of symptom development and also ensure that no other infections were missed within the 4 weeks. Our sample size may have also been too small to detect differences in colonisation between symptomatic and asymptomatic subjects, or for analysis of risk factors such as smoking and underlying disease as there were very few participants in these categories. We were unable to recruit the initially planned sample size so a larger scale study is warranted. The selected follow up period of 4 weeks was the maximal period of follow up possible within the available resources 
for the study, but longer follow up would be valuable. Finally, these results may not be generalised due to varying geographical distribution of pathogens and vaccine uptake by country.

\section{Conclusions}

In summary, we have found very high rates (almost 88\%) of bacterial colonisation, viral infection and co-infections in hospital HCWs, far higher than rates previously described in adults. Most studies show that adults have rates much lower than children, yet the rates we demonstrated exceeded even colonisation rates in children, possibly reflecting hospitals being a high exposure setting. Respiratory tract infections were also dynamic and changing over time, with different HCWs infected at baseline and the end of the study, with different pathogens. We were unable to determine the relationship of symptoms to colonisation because of a small sample size, but suggest larger studies are warranted. Our results suggest there is a continual ongoing risk of respiratory infection in hospitals HCWs.

\section{Abbreviations}

CDPC: Centre for Disease Prevention and Control; CRI: Clinical Respiratory Illness; HCW: Healthcare Worker; ICU: Intensive Care Unit; NAT: Nucleic acid testing; NP: Nasopharyngeal; PCR: Polymerase Chain Reaction; PPE: Personal Protective Equipment

\section{Acknowledgements}

Thanks to the staff at the Beijing Centre for Disease Control and hospitals staff. We also acknowledge the support of staff who participated in this study.

\section{Funding}

This study was supported by Australian National Health \& Medical Research Council of Australia (Grant \# 630787) and Centre for Research Excellence (Grant \# APP1107393).

\section{Availability of data and materials}

All data generated or analysed during this study are included in this published article.

\section{Authors' contributions}

CRM: lead investigator, responsible for conception and design of the study and writing the manuscript; $A A C$ and JC: data analysis and writing first draft of manuscript; $Y Z$ and PY: implementation and database management; $H S$, DZ, YP: recruitment and training, manuscript revision; QW: implementation, contribution to design, analysis and drafting of paper. All authors read and approved the final manuscript.

\section{Ethics approval and consent to participate}

The study protocol was approved by the Human Research Ethics Committee of the Beijing Ministry for Health and HREC University of New South Wales ( $\mathrm{HC} 14325)$. Consent was taken from all participants before the start of the study.

\section{Consent for publication}

Not applicable.

\section{Competing interests}

All authors have completed the Unified Competing Interest form (available on request from the corresponding author) and declare that;

1. Professor C. Raina MacIntyre: Raina MacIntyre has held an Australian Research Council Linkage Grant with $3 \mathrm{M}$ as the industry partner, for investigator driven research. $3 \mathrm{M}$ have also contributed supplies of masks and respirators for investigator-driven clinical trials. She has received research grants and laboratory testing as in-kind support from Pfizer, GSK and Bio-CSL for investigator-driven research

2. Dr. Holly Seale had a NHMRC Australian based Public Health Training Fellowship at the time of the study (1012631). She has also received funding from vaccine manufacturers GSK, bio-CSL and Saniofi Pasteur for investigator-driven research and presentations.

3. Dr. Abrar Chughtai had testing of filtration of masks by $3 \mathrm{M}$ for $\mathrm{PhD}$.

The remaining authors declare that they have no competing interests and have no non-financial interests that may be relevant to the submitted work.

\section{Publisher's Note}

Springer Nature remains neutral with regard to jurisdictional claims in published maps and institutional affiliations.

\section{Author details}

${ }^{1}$ School of Public Health and Community Medicine, UNSW Medicine, University of New South Wales, Level 2, Samuels Building, Sydney 2052, Australia. ${ }^{2}$ College of Public Service \& Community Solutions, Arizona State University, Phoenix, AZ, USA. ${ }^{3}$ The Beijing Centre for Disease Prevention and Control, Beijing, China.

Received: 10 May 2017 Accepted: 28 July 2017

Published online: 09 August 2017

References

1. Bogaert D, De Groot R, Hermans PW. Streptococcus Pneumoniae colonisation: the key to pneumococcal disease. Lancet Infect Dis. 2004;4(3):144-54.

2. Faden H, Duffy L, Wasielewski R, Wolf J, Krystofik D, Tung Y. Relationship between nasopharyngeal colonization and the development of otitis media in children. Tonawanda/Williamsville pediatrics. J Infect Dis. 1997;175(6):1440-5.

3. Givon-Lavi N, Fraser D, Porat N, Dagan R. Spread of Streptococcus Pneumoniae and antibiotic-resistant S. Pneumoniae from day-care center attendees to their younger siblings. J Infect Dis. 2002;186(11):1608-14.

4. Henkle E, Irving SA, Naleway AL, Gaglani MJ, Ball S, Spencer S, et al. Comparison of laboratory-confirmed influenza and noninfluenza acute respiratory illness in healthcare personnel during the 2010-2011 influenza season. Infect Control Hosp Epidemiol. 35(5):538-46.

5. Klevens RM, Edwards JR, Richards CL, Horan TC, Gaynes RP, Pollock DA, et al. Estimating health care-associated infections and deaths in U.S. hospitals, 2002. Public Health Rep. 2007;122(2):160-6.

6. Komitova R, Kunchev A, Mihneva Z, Marinova L. Nosocomial transmission of measles among healthcare workers, Bulgaria, 2010. Euro Surveill. 2011;16:15.

7. Bellei N, Carraro E, Perosa AHS, Benfica D, Granato CFH. Influenza and rhinovirus infections among health-care workers. Respirology. 2007;12(1):100-3.

8. Hosoglu S, Tanrikulu AC, Dagli C, Akalin S. Tuberculosis among health care workers in a short working period. Am J Infect Control. 2005;33(1):23-6.

9. Sepkowitz KA. Occupationally acquired infections in health care workers: part I. Ann Intern Med. 1996;125(10):826-34

10. Scott RD. The direct medical costs of healthcare-associated infections in US hospitals and the benefits of prevention. 2009.

11. Alexander E, Travis S, Booms C, Kaiser A, Fry N, Harrison T, et al. Pertussis outbreak on a neonatal unit: identification of a healthcare worker as the likely source. J Hosp Infect. 2008;69(2):131-4.

12. Berg HF, Van Gendt J, Rimmelzwaan GF, Peeters MF, Van Keulen P. Nosocomial influenza infection among post-influenza-vaccinated patients with severe pulmonary diseases. J Infect. 2003;46(2):129-32.

13. Jourdain S, Smeesters PR, Denis O, Dramaix M, Sputael V, Malaviolle X, et al. Differences in nasopharyngeal bacterial carriage in preschool children from different socio-economic origins. Clin Microbiol Infect. 2011;17(6):907-14.

14. Mackenzie GA, Leach AJ, Carapetis JR, Fisher J, Morris PS. Epidemiology of nasopharyngeal carriage of respiratory bacterial pathogens in children and adults: cross-sectional surveys in a population with high rates of pneumococcal disease. BMC Infect Dis. 2010;10:304.

15. Garcia-Rodriguez JA, Fresnadillo Martinez MJ. Dynamics of nasopharyngeal colonization by potential respiratory pathogens. J Antimicrob Chemother. 2002;50(Suppl S2):59-73. 
16. Ingvarsson L, Lundgren $K$, Ursing J. The bacterial flora in the nasopharynx in healthy children. Acta Otolaryngol. 1982;93(sup386):94-6.

17. Watson K, Carville K, Bowman J, Jacoby P, Riley TV, Leach AJ, et al. Upper respiratory tract bacterial carriage in aboriginal and non-aboriginal children in a semi-arid area of Western Australia. Pediatr Infect Dis J. 2006;25(9):782-90.

18. Sung RY, Ling JM, Fung SM, Oppenheimer SJ, Crook DW, Lau JT, et al. Carriage of Haemophilus influenzae and Streptococcus pneumoniae in healthy Chinese and Vietnamese children in Hong Kong. Acta paediatr (Oslo, Norway: 1992). 1995;84(11):1262-7.

19. Dhakal R, Sujatha S, Parija SC, Bhat BV. Asymptomatic colonization of upper respiratory tract by potential bacterial pathogens. Indian J Pediatr. 2010; 77(7):775-8.

20. Principi N, Marchisio P, Schito GC, Mannelli S. Risk factors for carriage of respiratory pathogens in the nasopharynx of healthy children. Pediatr Infect Dis J. 1999;18(6):517-23.

21. Ridda I, Macintyre C, Lindley R, McIntyre P, Brown M, Oftadeh S, et al. Lack of pneumococcal carriage in the hospitalised elderly. Vaccine. 2010;28(23):3902-4.

22. Carrat F, Vergu E, Ferguson NM, Lemaitre M, Cauchemez S, Leach S, et al. Time lines of infection and disease in human influenza: a review of volunteer challenge studies. Am J Epidemiol. 2008;167(7):775-85.

23. Kapikian AZ, Chanock RM, Reichelderfer TE, Ward TG, Huebner RJ, Bell JA. Inoculation of human volunteers with parainfluenza virus type 3. JAMA. 1961;178(6):537-41.

24. Muchmore HG, Parkinson AJ, Humphries JE, Scott EN, DA MI, Scott LV, et al. Persistent parainfluenza virus shedding during isolation at the South Pole. Nat. 1981;289(5794):187-9.

25. Carrat F, Sahler C, Rogez S, Leruez-Ville M, Freymuth F, Le Gales C, et al. Influenza burden of illness: estimates from a national prospective survey of household contacts in France. Arch Intern Med. 2002;162(16):1842-8.

26. Center for Disease Control and Prevention (CDC). Epi Info'M 2017 [Available from: https://www.cdc.gov/epiinfo/index.html.

27. Hendley JO, Sande MA, Stewart PM, Gwaltney JM Jr. Spread of Streptococcus Pneumoniae in families. I. Carriage rates and distribution of types. J Infect Dis. 1975;132(1):55-61.

28. Regev-Yochay G, Raz M, Dagan R, Porat N, Shainberg B, Pinco E, et al. Nasopharyngeal carriage of Streptococcus Pneumoniae by adults and children in community and family settings. Clin Infect Dis. 2004;38(5):632-9.

29. Hayward AC, Fragaszy EB, Bermingham A, Wang L, Copas A, Edmunds WJ, et al. Comparative community burden and severity of seasonal and pandemic influenza: results of the Flu Watch cohort study. Lancet Respir Med. 2(6):445-54.

30. Diavatopoulos DA, Short KR, Price JT, Wilksch JJ, Brown LE, Briles DE, et al. Influenza a virus facilitates Streptococcus Pneumoniae transmission and disease. FASEB J. 2010;24(6):1789-98.

31. Klugman KP, Chien Y-W, Madhi SA. Pneumococcal pneumonia and influenza: a deadly combination. Vaccine. 2009;27:C9-C14.

32. Kim EK, Youn YS, Rhim JW, Shin MS, Kang JH, Lee KY. Epidemiological comparison of three mycoplasma pneumoniae pneumonia epidemics in a single hospital over 10 years. Korean J Pediatr. 2015;58(5):172-7.

33. Hastings DL, Harrington KJ, Kutty PK, Rayman RJ, Spindola D, Diaz MH, et al. Mycoplasma pneumoniae outbreak in a long-term care facility-Nebraska, 2014. MMWR Morb Mortal Wkly Rep. 2015;64(11):296-9.

34. Bassinet L, Matrat M, Njamkepo E, Aberrane S, Housset B, Guiso N. Nosocomial pertussis outbreak among adult patients and healthcare workers. Infect Control Hosp Epidemiol. 2004;25(11):995-7.

35. Hyman CL, Roblin PM, Gaydos CA, Quinn TC, Schachter J, Hammerschlag MR. Prevalence of asymptomatic nasopharyngeal carriage of chlamydia pneumoniae in subjectively healthy adults: assessment by polymerase chain reaction-enzyme immunoassay and culture. Clin Infect Dis. 1995; 20(5):1174-8

36. Conklin L, Adjemian J, Loo J, Mandal S, Davis C, Parks S, et al. Investigation of a chlamydia pneumoniae outbreak in a federal correctional facility in Texas. Clin Infect Dis. 2013;57(5):639-47.

37. Klugman KP, Chien Y-W, Madhi SA. Pneumococcal pneumonia and influenza: A deadly combination. Vaccine. 2009;27(Supplement 3(0)):C9-C14.

38. Kuster SP, Shah PS, Coleman BL, Lam P-P, Tong A, Wormsbecker A, et al. Incidence of influenza in healthy adults and healthcare workers: a systematic review and meta-analysis. PLoS One. 2011;6(10):e26239.

39. Weber DJ, Rutala WA, Schaffner W. Lessons learned: protection of healthcare workers from infectious disease risks. Crit Care Med. 2010;38: S306-S14.
40. Marshall C, Kelso A, McBryde E, Barr IG, Eisen DP, Sasadeusz J, et al. Pandemic (H1N1) 2009 risk for frontline health care workers. Emerg Infect Dis. 2011;17(6):1000.

41. Loeb M, McGeer A, McArthur M, Walter S, Simor AE. Risk factors for pneumonia and other lower respiratory tract infections in elderly residents of long-term care facilities. Arch Intern Med. 1999;159(17):2058-64.

42. Maclntyre CR, Wang Q, Rahman B, Seale H, Ridda I, Gao Z, et al. Efficacy of face masks and respirators in preventing upper respiratory tract bacterial colonization and co-infection in hospital healthcare workers. Prev Med. 2014;62:1-7.

\section{Submit your next manuscript to BioMed Central and we will help you at every step:}

- We accept pre-submission inquiries

- Our selector tool helps you to find the most relevant journal

- We provide round the clock customer support

- Convenient online submission

- Thorough peer review

- Inclusion in PubMed and all major indexing services

- Maximum visibility for your research

Submit your manuscript at www.biomedcentral.com/submit
Biomed Central 